\title{
TÖBBFUNKCIÓS MEGMUNKÁLÓKÖZPONTOK ÖSSZEHASONLÍTÁSA
}

\section{COMPARISON OF MULTITASKING MACHINING CENTERS}

\author{
Mallár Tamás ${ }^{1}$, Turbucz Viktor ${ }^{2}$ \\ Óbudai Egyetem Bánki Donát Gépész és Biztonságtechnikai Mérnöki Kar, Bánki \\ Donát Szakkollégium, H-1081, Magyarország, Budapest, Népszínház utca, 8. \\ 'mallartamas@gmail.com \\ turbuczv@protonmail.com
}

\begin{abstract}
The tools to satisfy nowadays increased production needs are the multitasking machining centers. With these machines, all of the shaping processes can be done in one uptake. In our treatise, we show the comparison of these machines with standard terms declared by us. Our chosen terms' goal is to decrease the number of the machines from a dozen to a few. Furthermore, we defined shaping concentration as a notion to support the reducting process.
\end{abstract}

Keywords: multitasking, machining center, done in one, shaping concentration

\section{Összefoglalás}

Napjaink megnövekedett termelési igényeinek kielégítésére szolgáló szerszámgépek a többfunkciós megmunkálóközpontok. Ezekkel a berendezésekkel az összes megmunkálási müvelet egy felfogásban elvégezhető. Tanulmányunkban ezen gépek összehasonlítását mutatjuk be általunk meghatározott, egységes szempontok alapján. A támasztott követelmények célja az, hogy a rendelkezésre álló paraméterek alapján a több tucat gépet néhány darabra redukáljuk. E szúkítést szolgálja továbbá az általunk definiált megmunkálási koncentráltság fogalma is.

Kulcsszavak: többfunkciós, megmunkálóközpont, egylépéses megmunkálás, megmunkálási koncentráltság

\section{Bevezetés, célkitűzések}

Napjaink legkorszerúbb tö CNC
szerszámgépei a többfunkciós
megmunkálóközpontok. Ez a definíció más
és más alakban jelenik meg a különböző
gyártóknál. Például a Mazak a többfunkciós
megmunkálóközpont, a DMG-Mori a
komplett eszterga é a maró
megmunkálóközpont kifejezést használja,
míg az Index-Traub eszterga/maró
központnak, az Okuma pedig többfeladatú

gépnek hívja ilyen funkciójú termékeit. Általánosan elmondható, hogy ezek a szerszámgépek rendelkeznek egy eszterga fö- és ellenorsóval, egy maróorsóval és legalább egy revolverfejjel. Ezekkel a berendezésekkel az összes megmunkálási müvelet egy felfogásban, egyszerre több szerszámmal végezhető el, így növelve a munkadarab pontosságát és csökkentve a gépidőt.

Egy ilyen gép általános felépítése látható az 1. ábrán. 


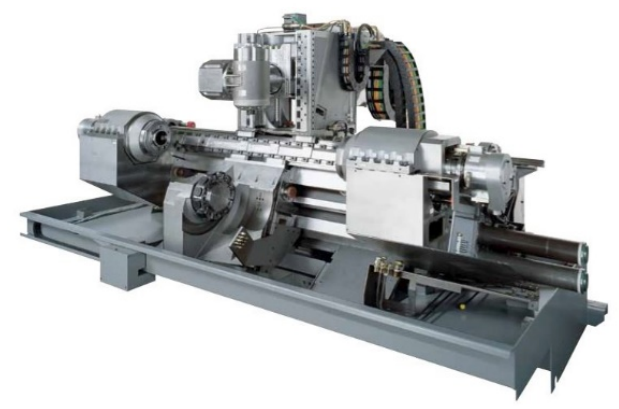

1. ábra. A vizsgált gépek általános felépitése [8]

\section{Peremfeltételek és gépek}

Az általunk megszabott peremfeltételek a következők:

-ágyméret: 4 méternél nem nagyobb;

- eszterga fö- és ellenorsó homlokmérete:

A2-8;

- szerszámtartó kivitele: BT40, vagy HSKA63;

- tetszőlegesen nagy szerszámtár.

$\mathrm{Az}$ ágyméret és az esztergaorsók homlokmérete alapvetően meghatározza a megmunkálható munkadarab méreteit. Összehasonlításunkban a kis- és közepes méretü munkadarabok megmunkálására alkalmas szerszámgépeket vizsgáljuk.

A gépre szerelhető szerszámtartónak kellöen korszerünek kell lennie, mert az újabb szabványok szerint készült tartókkal kedvezőbbek a megmunkálási körülmények.

A szerszámtárba helyezhető szerszámok száma döntően befolyásolja a felszerszámozással töltött időt. Ezért minél több szerszámmal van felszerelve egy gép, annál tovább tud megszakítások nélkül üzemelni, ezáltal csökken a mellékidő.

Szakirodalomkutatás után az 1. táblázatban szereplő eredményre jutottunk:
1. táblázat. Gyártók, gépcsaládok, szériák

\begin{tabular}{|c|c|c|}
\hline Mazak & Integrex & $\mathrm{e}$ - széria \\
\cline { 3 - 3 } & & $\mathrm{i}$ - széria \\
\cline { 3 - 3 } & & $\mathrm{j}$ - széria \\
\hline \multirow{2}{*}{ DMG-Mori } & $\mathrm{CTX}$ & $\mathrm{Gamma} \mathrm{TC}$ \\
\cline { 2 - 3 } & $\mathrm{NT}$ & $\mathrm{DCG}$ S/SZ \\
\cline { 2 - 3 } & $\mathrm{NTX}$ & $\mathrm{S} / \mathrm{SZ}$ \\
\hline \multirow{2}{*}{ Index } & - & $\mathrm{G}$-széria \\
\cline { 3 - 3 } & & $\mathrm{R}$-széria \\
\hline Okuma & Multus & B-széria \\
\hline
\end{tabular}

A keresés során szóba kerültek több másik szerszámgépgyártó cég (például Haas, Matsuura stb.) gépei is, mivel azonban ezek nem elégítettek ki maradéktalanul minden feltételt, nem kerültek bele összehasonlításunkba.

\section{Optimális gépek}

A korábban definiált peremfeltételeket a következőképpen módosítottuk:

-ágyméret: 1,2-3 méter;

- szerszámtartó kivitele: HSK-A63;

- eszterga fóorsó fordulatszáma: 3000

$1 / \mathrm{min}$;

- maróorsó fordulatszáma: 12000 1/min;

- revolverfej megléte.

A meghatározott ágy- és esztergaorsó méret lefedi az általunk peremfeltételként megszabott kis- és közepes méretü munkadarabok megmunkálásához alkalmas berendezéseket.

Kellően modern szerszámtartókra van szükség az eszterga és maró szerszámok közötti átjárhatóság érdekében, ezért választottuk a fent említett HSK-A63-as szabványt. Így lehetségessé válik az álló maróorsóval történő "kontúrkövetö" esztergálás, melynek során kedvezőbbek a forgácsolási feltételek.

A termelékeny forgácsolás biztosításához az általunk meghatározott fordulatszámok tekinthetők elvártnak.

Az ilyen módon pontosított feltételek alapján a 2. táblázatban látható gépeket találtuk optimálisnak. 
2. táblázat. A családonként kiválasztott gépek

\begin{tabular}{|c|c|c|}
\hline Mazak & Integrex & $\mathrm{e}-420 \mathrm{H}-\mathrm{ST} / 2000$ \\
\cline { 3 - 3 } & & $\mathrm{i}-300 \mathrm{ST} / 1500$ \\
\cline { 3 - 3 } & & $\mathrm{j}-300 / 1200$ \\
\hline \multirow{2}{*}{$\begin{array}{c}\text { DMG- } \\
\text { Mori }\end{array}$} & $\mathrm{CTX}$ & Gamma 3000TC (4A) \\
\cline { 2 - 3 } & $\mathrm{NT}$ & $4250 \mathrm{DCG} / 1500 \mathrm{~S} / \mathrm{SZ}$ \\
\cline { 2 - 3 } & $\mathrm{NTX}$ & $2000 \mathrm{SZM}$ \\
\hline Index & - & $\mathrm{G} 400$ \\
\hline
\end{tabular}

\section{Megmunkálási koncentráltság}

Az elözőleg ismertetett szürési paramétereket bővítjük az úgynevezett megmunkálási koncentráltsággal, mely egyenlő a gépen található megmunkálást végző egységek számának és a berendezés alapterületének hányadosával.

A megmunkálást végző egységek számát úgy határoztuk meg, hogy megnéztük egy alkatrészhez egyszerre hány darab modul férhet hozzá. Néhány gép esetében a maróorsóval egybe van építve egy revolverfej, de mivel ezek közül egyszerre csak az egyik tud dolgozni, ezek számát egynek vettük.

Azonban a müveleti koncentráltság csak egy viszonyszám, amit a gépek rangsorolásához definiáltunk. Ebben a formában sehol nem alkalmazzák, ennek ellenére gépvásárláskor a megmunkáló egységek száma és a megmunkálóközpontok alapterülete döntő befolyással bír.

A 2. táblázatban ismertetett típusok megmunkálási koncentráltsága a 3. táblázatban olvasható. A kapott eredmények alapján az általunk legjobbnak deklarált többfunkciós megmunkálóközpont az Index G400 lett, melytől alig marad el a Mazak i-300ST.

\section{Következtetések}

Legfőbb célunk az volt, hogy a mai modern ipari igényeknek megfelelö többfunkciós megmunkálóközpontokat kellő mélységben összehasonlítsuk, valamint kiemeljük az általunk legjobbnak találtakat. Munkánk során betekintést nyertünk a szerszámgépek felépítésébe, a konstrukciós megoldásokba, a főbb gyártási szempontokba és a vállalatok marketing tevékenységébe is. Szándékunkban állt egy gazdasági szempontok szerinti összehasonlítás készítése is, erre azonban nem kerülhetett sor, mivel nem gazdasági társaságként kértünk árajánlatot, így elutasították ezen kérésünket. Következtetéseinket a 3. táblázatban foglaltuk össze, ezek alapján mi az Index G400-as gépét választanánk.

3. táblázat. Az egyes gépek megmunkálási koncentráltsága

\begin{tabular}{|c|c|c|c|c|c|c|c|}
\hline \multirow{2}{*}{ Gyártó } & \multicolumn{3}{|c|}{ DMG - Mori } & \multicolumn{3}{c|}{ Mazak } & Index \\
\hline Család & CTX & NT & NTX & \multicolumn{3}{c|}{ Integrex } & - \\
\hline Típus & $\begin{array}{c}\text { Gamma } \\
3000 \mathrm{TC}\end{array}$ & $\begin{array}{c}4250 \\
\text { DCG SZ }\end{array}$ & $\begin{array}{c}2000 \\
\text { SZM }\end{array}$ & $\begin{array}{c}\text { e420H- } \\
\text { ST }\end{array}$ & i-300 ST & j-300 & G400 \\
\hline Alapter. [m $\left.{ }^{2}\right]$ & 31,9695 & 17,3841 & 15,9 & 22,3236 & 13,748 & 13,0652 & 16,4205 \\
\hline $\begin{array}{c}\text { Megmunk. egys. } \\
\text { sz. [db] }\end{array}$ & 4 & 4 & 4 & 4 & 4 & 3 & 5 \\
\hline $\begin{array}{c}\text { Megmunk. konc. } \\
{\left[\mathrm{db} / \mathrm{m}^{2}\right]}\end{array}$ & 0,1251 & 0,2301 & 0,2526 & 0,1792 & 0,2910 & 0,2296 & 0,3045 \\
\hline
\end{tabular}




\section{Szakirodalmi hivatkozások}

[1] http://en.dmgmori.com/blob/230242/987f7d0 9045c81d2b7fba716e27a5c98/pt0uk-ctxbeta-tc-pdf-data.pdf

[2] http://en.dmgmori.com/blob/123332/2dcd64a $\underline{8100 \mathrm{baebf0a} 08 \mathrm{f} 45904 \mathrm{bf} 6 \mathrm{c} 4 \mathrm{~d} / \mathrm{pt} 0 \mathrm{uk} 13 \text {-ctx-tc- }}$ series-pdf-data.pdf

[3] http://en.dmgmori.com/blob/163706/71138e 7d95a5bf3d355c0e878b02e9ed/pt0uk14-ntseries-pdf-data.pdf

[4] http://en.dmgmori.com/blob/335802/59d8d2 11da8edf4a8a3504074e31074b/pt1uk15-ntx1000-2--gen--pdf-data.pdf

[5] http://en.dmgmori.com/blob/383676/93clcd8 5d6b7d6d2c3ed2508c5f19829/pt0uk15-ntx2000-pdf-data.pdf

[6] http://www.indextraub.com/fileadmin/user upload/INDEX/G2 00/INDEX_G200_EN.pdf

[7] http://www.indextraub.com/fileadmin/user upload/INDEX/G2 20/INDEX G220 EN.pdf
[8] http://www.indextraub.com/fileadmin/user upload/INDEX/G4 00/INDEX G250 G400 EN.pdf

[10] http://www.indextraub.com/fileadmin/user upload/INDEX/R2 00/INDEX R200 EN.pdf

[11] http://www.indextraub.com/fileadmin/user upload/INDEX/R3 00/INDEX R300 EN.pdf

[12] http://www.indextraub.com/fileadmin/user upload/TRAUB/T NX65 42/TRAUB TNX65-42 EN.pdf

[13] DMG MORI Global Marketing Gmbh NT-series, electronic catalogue (2016)

[14] Yamazaki Mazak Corporation - Integrex eH-series, press catalogue (2016)

[15] Yamazaki Mazak Corporation - Integrex jseries, press catalogue (2016)

[16] Yamazaki Mazak Corporation - Integrex Total Line-Up, press catalogue (2016)

[17] Yamazaki Mazak Corporation - Mazak, nyomtatott fökatalógus (2016)

[18] OKUMA Corporation - Multus BII series, electronic catalogue (2015) 